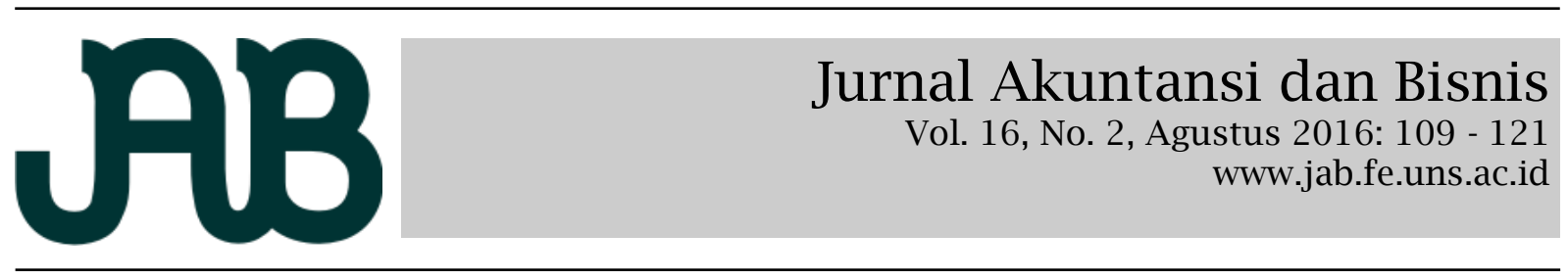

\title{
ANALISIS FAKTOR-FAKTOR YANG MEMPENGARUHI KUALITAS HASIL PEMERIKSAAN AUDIT PEMERINTAH (STUDI EMPIRIS PADA BPKP PERWAKILAN PROVINSI DKI JAKARTA)
}

\section{REZA FERDIANSYAH}

Badan Pengawas Keuangan dan Pembangunan Republik Indonesia (BPKP-RI)

\begin{abstract}
A B S TRACT
This study aims to determine effect of audit time limit, work experience, independence, objectivity, integrity and competence of the auditors on the quality of government audit examination results. This study used primary data obtained through a questionnaire distributed to all auditors in BPKP representatives of DKI Jakarta Province. Criteria samples of this study is auditor has to follow JFA. The questionnaire comprised of 68 questions and measured with Likert scale 1-5. Hypothesis testing is done by using SPSS with multiple linear regression model with significance level of $10 \%$. The results of multiple regression analysis showed that independence, integrity and competence have positive effect of the government auditor and significant impact on the quality of examination results produced. While, time audit limit, work experience and objectivity of government auditor doesn't effect on the quality of examination results.

Keywords: audit time limit, work experience, independence, objectivity, integrity, auditor competency, quality of examination results government audit

Penelitian ini bertujuan untuk mengetahui pengaruh bahwa batasan waktu audit, pengalaman kerja, independensi, objektifitas, integritas, dan kompetensi auditor terhadap kualitas hasil pemeriksaan audit pemerintah. Penelitian ini menggunakan data primer yang diperoleh dengan menggunakan kuesioner yang didistribusikan langsung kepada seluruh auditor pada Badan Pengawasan Keuangan dan Pembangunan (BPKP) Perwakilan Provinsi D.K.I Jakarta. Penentuan sampel dengan kritera bahwa auditor tersebut telah mengikuti Pendidikan dan Pelatihan Jabatan Fungsional Auditor (JFA). Kuisioner terdiri dari 68 pertanyaan dan diukur dengan skala Likert 15. Pengujian hipotesis dilakukan dengan menggunakan aplikasi SPSS dengan model persamaan regresi linear berganda dengan level signifikansi 10\%. Hasil analisis regresi berganda menunjukkan bahwa independensi, integritas dan kompetensi auditor pemerintah berpengaruh positif dan signifikan terhadap kualitas hasil pemeriksaan yang dihasilkan. Sedangkan batasan waktu audit, pengalaman kerja audit, dan obyektifitas auditor pemerintah tidak berpengaruh terhadap kualitas hasil pemeriksaan.

Kata kunci: batasan waktu audit, pengalaman kerja, independensi, objektifitas, integritas, kompetensi auditor, kualitas hasil pemeriksaan audit pemerintah
\end{abstract}

\section{PENDAHULUAN}

Terdapat tiga aspek utama yang mendukung terciptanya kepemerintahan yang baik (good governance), yaitu pengawasan, pengendalian, dan pemeriksaan. Pengawasan merupakan kegiatan yang dilakukan oleh pihak di luar eksekutif, yaitu masyarakat dan Dewan Perwakilan Rakyat Daerah (DPRD) untuk mengawasi kinerja pemerintahan. Pengendalian (control) adalah mekanisme yang dilakukan oleh eksekutif untuk menjamin bahwa sistem dan kebijakan manajemen dilaksanakan dengan baik sehingga tujuan organisasi dapat tercapai. Pemeriksaan (audit) merupakan kegiatan yang dilakukan oleh pihak yang memiliki independensi dan memiliki kompetensi profesional untuk memeriksa apakah hasil kinerja pemerintah telah sesuai dengan standar yang ditetapkan (Mardiasmo 2002).

Proses pengawasan dan pemeriksaan atas pengelolaan keuangan negara di Indonesia dilakukan oleh seorang auditor 
pemerintah, yaitu: Inspektorat Jenderal Kementerian, Satuan Pengawas Intern (SPI) dilingkungan lembaga Negara dan BUMN/ BUMD, Inspektorat wilayah Propinsi (Itwilprop), Inspektorat Wilayah Kabupaten/kota (Itwilkab/Itwilkot), Badan Pengawasan Keuangan dan Pembangunan (BPKP) dan Badan Pemeriksa Keuangan (BPK) yang merupakan lembaga pemeriksa (auditor) eksternal yang independen.

Auditor sektor publik (pemerintah) yang berada di instansi BPK dan BPKP selain dituntut untuk mematuhi ketentuan dan peraturan kepegawaian sebagai PNS, mereka juga dituntut untuk menaati kode etik Aparat Pengawasan Intern Pemerintah (APIP) serta standar audit APIP atau standar audit lainnya yang telah ditetapkan. Kegiatan utama APIP meliputi antara lain: audit, review, pemantauan, evaluasi, dan kegiatan pengawasan lainnya berupa sosialisasi, asistensi, dan konsultansi. Pengawasan bersifat membantu agar sasaran yang ditetapkan organisasi dapat tercapai, dan secara dini menghindari terjadinya penyimpangan pelaksanaan, penyalahgunaan wewenang, pemborosan dan kebocoran.

Perilaku auditor yang seharusnya menjaga kepercayaan masyarakat namun menyalahgunakannya merupakan sikap yang tidak beretika. Sebagai contoh konkret, adanya oknum Badan Pemeriksa Keuangan (BPK) Jawa barat sebagai auditor pemerintah dan bekerja atas nama rakyat Indonesia yang telah melakukan jual beli opini kepada pejabat Pemerintah Kabupaten Bekasi pada tahun 2010. Auditor BPK sebagai perwakilan rakyat Indonesia seharusnya melakukan audit dengan penuh integritas, obyektifitas dan independensi.

Perilaku menyimpang oknum auditor BPK tersebut jelas membuat kepercayaan masyarakat terhadap institusi akuntan pemerintah berada pada titik yang memprihatinkan. Oknum auditor tersebut telah melakukan manipulasi terhadap kualitas audit yang seharusnya terjaga dengan baik. Selain itu, secara tidak langsung oknum tersebut telah melakukan kebohongan terhadap publik berkaitan dengan opini audit yang dihasilkan.
Kode Etik APIP dalam Peraturan Menteri Negara Pendayagunaan Aparatur Negara (PERMENPAN) Nomor PER/04/ M.PAN/03/2008, salah satu tujuannya adalah mencegah terjadinya tingkah laku yang tidak etis. Tujuan lain adalah agar terpenuhi prinsip-prinsip kerja yang akuntabel dan terlaksananya pengendalian audit sehingga terwujud auditor yang kredibel dengan kinerja yang optimal dalam pelaksanaan audit. Prinsip-prinsip perilaku yang berlaku bagi auditor antara lain integritas, obyektifitas dan kompetensi. Integritas diperlukan agar auditor dapat bertindak jujur dan tegas dalam melaksanakan audit; obyektifitas diperlukan agar auditor dapat bertindak adil tanpa dipengaruhi oleh tekanan atau permintaan pihak tertentu yang berkepentingan atas hasil audit; serta kompetensi auditor didukung oleh pengetahuan, dan kemampuan yang diperlukan untuk melaksanakan tugas.

Standar Audit APIP sebagaimana diatur dalam PERMENPAN Nomor PER/05/ M.PAN/03/2008, merupakan acuan bagi seluruh APIP dalam melaksanakan audit. Standar audit tersebut mengatur tentang independensi APIP dan obyektifitas auditor. Dalam standar umum disebutkan bahwa "dalam semua hal yang berkaitan dengan audit, APIP harus independen dan para auditornya harus obyektif dalam pelaksanaan tugasnya". Standar tersebut mewajibkan auditor sektor publik untuk selalu bersikap independen serta obyektif dalam pelaksanaan tugas agar kualitas hasil auditnya meningkat.

Penelitian sebelumnya oleh Christiawan (2002) menyatakan Kompetensi dan independensi berpengaruh signifikan terhadap kualitas audit. Kemudian penelitian yang dilakukan Alim et al. (2007) memperoleh hasil kompetensi dan independensi berpengaruh signifikan terhadap kualitas audit. Penelitian Nataline (2007) menyimpulkan batasan waktu audit, pengetahuan audit, pemberian bonus dan pengalaman kerja berpengaruh signifikan terhadap kualitas audit. Suraida (2005) menyatakan bahwa pengalaman audit dan kompetensi berpengaruh terhadap skeptisisme profesional dan ketepatan pemberian opini auditor akuntan publik. Begitu juga penelitian 
yang dilakukan Sukriah et al. (2009), diperoleh kesimpulan bahwa pengalaman kerja, obyektifitas dan kompetensi berpengaruh positif terhadap kualitas hasil pemeriksaan. Sedangkan untuk independensi dan integritas tidak berpengaruh signifikan terhadap kualitas hasil pemeriksaan.

Tujuan penelitian ini adalah untuk menguji pengaruh batasan waktu audit, pengalaman kerja, independensi, objektifitas, integritas dan kompetensi terhadap kualitas hasil pemeriksaan yang dihasilkan oleh auditor pemerintah. Responden dalam penelitian ini adalah auditor pemerintah sebagai PNS yang bekerja pada kantor BPKP Perwakilan Provinsi DKI Jakarta.

\section{TINJAUAN PUSTAKA DAN PENGEM- BANGAN HIPOTESIS \\ Teori Atribusi}

Menurut Fritz Heider pencetus teori atribusi, teori atribusi merupakan teori yang menjelaskan tentang perilaku seseorang. Teori atribusi menjelaskan mengenai proses bagaimana kita menentukan penyebab dan motif tentang perilaku seseorang. Teori ini mengacu tentang bagaimana seseorang menjelaskan penyebab perilaku orang lain atau dirinya sendiri yang akan ditentukan apakah dari internal misalnya sifat, karakter, sikap, dll ataupun eksternal misalnya tekanan situasi atau keadaan tertentu yang akan memberikan pengaruh terhadap perilaku individu (Luthans 2005).

Teori atribusi menjelaskan tentang pemahaman akan reaksi seseorang terhadap peristiwa di sekitar mereka, dengan mengetahui alasan-alasan mereka atas kejadian yang dialami. Teori atribusi dijelaskan bahwa terdapat perilaku yang berhubungan dengan sikap dan karakteristik individu, maka dapat dikatakan bahwa hanya melihat perilakunya akan dapat diketahui sikap atau karakteristik orang tersebut serta dapat juga memprediksi perilaku seseorang dalam menghadapi situasi tertentu.

Dalam hidupnya, seseorang akan membentuk ide tentang orang lain dan situasi disekitarnya yang menyebabkan perilaku seseorang dalam persepsi sosial yang disebut dengan dispositional atributions dan situational attributions (Luthans 2005). Dispositional attributions atau penyebab internal yang mengacu pada aspek perilaku individual yang ada dalam diri seseorang seperti kepribadian, persepsi diri, kemampuan, motivasi. Sedangkan situational attributions atau penyebab eksternal yang mengacu pada lingkungan sekitar yang dapat mempengaruhi perilaku, seperti kondisi sosial, nilai-nilai sosial, dan pandangan masyarakat. Dengan kata lain, setiap tindakan atau ide yang akan dilakukan oleh seseorang akan dipengaruhi oleh faktor internal dan faktor eksternal individu tersebut.

Psikolog terkenal, Harold Kelley dalam Luthans (2005) menekankan bahwa teori atribusi berhubungan dengan proses kognitif dimana individu menginterprestasikan perilaku berhubungan dengan bagian tertentu dari lingkungan yang relevan. Ahli teori atribusi mengamsusikan bahwa manusia itu rasional dan didorong untuk mengidentifikasi dan memahamai struktur penyebab dari lingkungan mereka. Inilah yang menjadi ciri teori atribusi.

Fritz Heider juga menyatakan bahwa kekuatan internal (atribut personal seperti kemampuan, usaha dan kelelahan) dan kekuatan eksternal (atribut lingkungan seperti aturan dan cuaca) itu bersama-sama menentukan perilaku manusia. Dia menekankan bahwa merasakan secara tidak langsung adalah determinan paling penting untuk perilaku. Atribusi internal maupun eksternal telah dinyatakan dapat mempengaruhi terhadap evaluasi kinerja individu, misalnya dalam menentukan bagaimana cara atasan memperlakukan bawahannya, dan mempengaruhi sikap dan kepuasaan individu terhadap kerja. Orang akan berbeda perilakunya jika mereka lebih merasakan atribut internalnya daripada atribut eksternalnya.

Dalam penelitian ini, peneliti menggunakan teori atribusi karena peneliti akan melakukan studi empiris untuk mengetahui faktor-faktor yang mempengaruhi auditor terhadap kualitas hasil audit, khususnya pada karakteristik personal auditor itu sendiri. Pada dasarnya 
karakteristik personal seorang auditor merupakan salah satu penentu terhadap kualitas hasil audit yang akan dilakukan karena merupakan suatu faktor internal yang mendorong seseorang untuk melakukan suatu aktivitas.

\section{Batasan Waktu Audit}

Dalam SPAP (SA Seksi 326, PSA No 07) menyebutkan bahwa auditor bekerja dalam batas-batas pertimbangan ekonomi agar secara ekonomis bermanfaat, pendapatnya harus dirumuskan dalam jangka waktu yang pantas. Auditor harus memutuskan, sekali lagi dengan menggunakan pertimbangan profesionalnya, apakah bukti audit yang tersedia dengan batasan waktu cukup memadai untuk membenarkan pernyataan pendapatnya.

Auditor menetapkan alokasi waktu audit yang sangat ketat, tetapi akibatnya memiliki efek samping yang merugikan publik, yaitu memunculkan perilaku yang mengancam kualitas audit, antara lain penurunan tingkat pendeteksian dan penyelidikan aspek kualitatif salah saji, gagal meneliti prinsip akuntansi, melakukan review dokumen secara dangkal, menerima penjelasan klien secara lemah dan mengurangi pekerjaan pada salah satu langkah audit di bawah tingkat yang diterima Kelley dan Margheim (2001) dalam Nataline (2007).

\section{Pengalaman kerja}

Pengalaman kerja adalah proses pembentukan pengetahuan atau keterampilan tentang metode suatu pekerjaan karena keterlibatan karyawan tersebut dalam pelaksanaan tugas pekerjaan Manulang (1984). Dalam pekerjaan profesional auditing, pendidikan formal saja tidak cukup untuk menghasilkan auditor yang profesional dan berkualitas tinggi. Dibutuhkan adanya pengalaman kerja dalam mendukung kesuksesan sebagai auditor yang berkualitas. Pengalaman bagi auditor merupakan nilai tambah bagi dirinya dan dapat mendukung terciptanya kualitas audit yang diharapkan.

Pengalaman kerja bagi auditor dapat berupa pengalaman dalam melakukan au- dit laporan keuangan baik dari segi lamanya waktu maupun banyaknya penugasan yang pernah ditangani (Suraida 2005). Auditor yang semakin berpengalaman cenderung mempunyai keunggulan dan kreatifitas dalam mendeteksi, memahami dan mencari sebab dari suatu kesalahan/manipulasi oleh auditee.

\section{Independensi}

Independensi diartikan sebagai sikap mental yang bebas dari pengaruh, tidak dikendalikan oleh pihak lain, tidak tergantung pada orang lain (Mulyadi 2002). Independensi juga berarti adanya kejujuran dalam diri auditor dalam mempertimbangkan fakta dan adanya pertimbangan yang obyektif tidak memihak dalam diri auditor dalam merumuskan dan menyatakan pendapatnya.

Independensi pada dasarnya merupakan state of mind atau sesuatu yang dirasakan oleh masing-masing (auditor) menurut apa yang diyakini sedang berlangsung (Pusdiklatwas BPKP 2008). Independensi auditor dapat ditinjau dan dievaluasi dari dua sisi, independensi praktisi dan independensi profesi.

Independensi praktisi yakni independensi yang nyata atau faktual yang diperoleh dan dipertahankan oleh auditor dalam seluruh rangkaian kegiatan audit, mulai dari tahap perencanaan, pelaksanaan, sampai tahap pelaporan. Sedangkan independensi profesi yakni independensi yang ditinjau menurut citra (image) auditor dari pandangan publik atau masyarakat umum terhadap auditor yang bertugas. Independensi menurut tinjauan ini sering pula dinamakan independensi dalam penampilan (independence in appearance).

\section{Obyektifitas}

Obyektifitas bagi auditor sektor publik diatur dalam kode etik APIP yang terdapat dalam Peraturan Menteri Negara Pendayagunaan Aparatur Negara (Permenpan) No.PER/05/M.PAN/03/2008 tentang Kode Etik APIP. Obyektifitas merupakan bagian dari prinsip-prinsip perilaku yang harus dipatuhi oleh auditor. Prinsip perilaku obyektifitas berbunyi: "Auditor harus men- 
junjung tinggi ketidakberpihakan profesional dalam mengumpulkan, mengevaluasi, dan memproses data/informasi auditi. Auditor APIP membuat penilaian seimbang atas semua situasi yang relevan dan tidak dipengaruhi oleh kepentingan sendiri atau orang lain dalam mengambil keputusan."

Obyektifitas auditor sektor publik wajib dijaga agar tidak terjadi negosiasi hasil audit yang dapat merugikan masyarakat. Kebijakan menjaga objektifitas dapat dituangkan dalam bentuk ketentuan seperti: tidak diperkenankannya seorang auditor sektor publik melakukan audit pada auditi tertentu selama 3 (tiga) tahun berturutturut, dilakukannya rotasi atau mutasi penugasan audit, larangan seorang auditor melakukan audit pada auditi yang pejabatnya memiliki hubungan keluarga, dan sebagainya.

\section{Integritas}

Prinsip integritas mengharuskan auditor untuk memiliki kepribadian yang dilandasi oleh unsur kejujuran, keberanian, bijaksana, dan bertanggung jawab untuk membangun kepercayaan guna memberikan dasar bagi pengambilan keputusan yang andal (Pusdiklatwas BPKP 2008).

Auditor sektor publik diharapkan selalu menjaga kejujuran dalam penugasan profesionalnya agar hasil audit yang dilaporkan dapat dipercaya oleh masyarakat. Selain itu sikap berani harus dimiliki oleh auditor sektor publik untuk membentengi diri dari tindakan tekanan oleh auditee. Auditor sektor publik juga dituntut untuk bersikap bijaksana dan bekerja penuh tanggung jawab dengan mengutamakan pada bukti audit yang cukup dan kompeten dalam pengungkapan hasil laporan audit.

\section{Kompetensi}

Kompetensi auditor sektor publik diatur dalam kode etik APIP yang terdapat dalam Peraturan Menteri Negara Pendayagunaan Aparatur Negara (Permenpan) No.PER/05/ M.PAN/03/2008 tentang Kode Etik APIP. Prinsip kompetensi menekankan auditor harus memiliki pengetahuan, keahlian, pengalaman dan keterampilan yang diperlukan untuk melaksanakan tugas. Perilaku kompetensi auditor sektor publik antara lain; tugas pengawasan sesuai dengan Standar Audit, selalu meningkatkan kemahiran profesi, keefektifan dan kualitas hasil pekerjaan, menolak untuk melaksanakan tugas apabila tidak sesuai dengan pengetahuan, keahlian, dan keterampilan yang dimiliki.

\section{Kualitas Hasil Pemeriksaan}

Kualitas audit merupakan probabilitas dimana seorang auditor menemukan dan melaporkan tentang adanya suatu pelanggaran dalam sistem akuntansi kliennya (De Angelo 1981). Kualitas hasil pemeriksaan juga berarti pelaporan tentang kelemahan pengendalian intern dan kepatuhan terhadap ketentuan, tanggapan dari pejabat yang bertanggung jawab, merahasiakan pengungkapan informasi yang dilarang, pendistribusian laporan hasil pemeriksaan dan tindak lanjut dari rekomendasi auditor sesuai dengan peraturan perundangundangan. Kualitas laporan audit kinerja haruslah tepat waktu, lengkap, akurat, obyektif, meyakinkan, serta jelas, dan seringkas mungkin, sesuai dengan standar pelaporan audit yang terdapat dalam Permenpan No. PER/05/M.PAN/03/2008.

\section{Pengembangan Hipotesis \\ Batasan Waktu Audit dan Kualitas Hasil Pemeriksaan}

Di bawah tekanan waktu, perhatian akan lebih terfokus pada tugas yang dominan seperti tugas pengumpulan bukti berkaitan dengan frekuensi dan jumlah salah saji dan mengorbankan perhatian yang diberikan pada tugas tambahan seperti tugas yang memberikan aspek kualitatif atas terjadinya salah saji yang menunjukkan potensial kecurangan pelaporan keuangan.

Penelitian yang dilakukan oleh Waggoner dan Cashell (dalam Nataline 2007) menunjukkan bahwa semakin banyak waktu yang diberikan, semakin banyak transaksi yang dapat dites oleh auditor. Hal ini serupa dengan penelitian Nataline (2007) yang menunjukkan bahwa para auditor yang semakin merasa adanya kelonggaran dalam menjalankan tugasnya akan 
berdampak positif terhadap kualitas hasil auditnya, sebaliknya dengan waktu yang semakin sempit akan mengurangi kualitas auditnya. Penelitian Josoprijonggo (dalam Nataline 2007) menyatakan bahwa batasan waktu audit mempunyai pengaruh negatif yang signifikan terhadap kualitas audit, artinya semakin tinggi tingkat batasan waktu audit, maka kualitas audit akan semakin menurun. Berdasarkan penjelasan di atas, maka hipotesis yang diajukan adalah sebagai berikut ini.

H1: Batasan waktu audit berpengaruh negatif terhadap kualitas hasil pemeriksaan audit pemerintah

\section{Pengalaman Kerja Audit dan Kualitas Hasil Pemeriksaan}

Teori atribusi mendukung pengaruh pengalaman kerja terhadap kualitas hasil audit. Perilaku seseorang disebabkan faktor internal. Banyaknya tugas-tugas pemeriksaan dan lamanya pengalaman kerja mengembangkan keahlian kualitas sumber daya manusia. Semakin lama masa kerja dan pengalaman yang dimiliki auditor, maka akan meningkatkan kualitas hasil audit yang dihasilkan. Hal tersebut sesuai hasil penelitian Alim et al. (2007), Sukriah et al. (2009), serta penelitian Mabruri dan Winarna (2010) yang menyimpulkan bahwa pengalaman kerja berpengaruh positif terhadap kualitas hasil pemeriksaan.

Dalam standar umum auditing, auditor disyaratkan memiliki pengalaman audit yang cukup agar mampu melaksanakan penugasan profesionalnya dengan baik. Sehingga diharapkan pengalaman yang sudah dimiliki akan meningkatkan kualitas hasil pemeriksaan yang dilakukan oleh auditor. Hal ini sesuai dengan pendapat Mulyadi (2002) yang menyatakan bahwa seorang yang memasuki karier sebagai akuntan publik, ia harus lebih dulu mencari pengalaman profesi dibawah pengawasan akuntan senior yang lebih berpengalaman. Berdasarkan penjelasan diatas, maka hipotesis yang diajukan adalah sebagai berikut ini.

H2: Pengalaman kerja audit berpengaruh positif terhadap kualitas hasil pemeriksaan audit pemerintah

\section{Independensi dan Kualitas Hasil Pemerik-} saan

Menurut Mulyadi (2002) independensi adalah sikap mental yang bebas dari pengaruh, tidak dikendalikan oleh pihak lain dan tidak tergantung pada orang lain. Bagi auditor, independensi merupakan sikap yang melekat pada dirinya dan harus dijaga dalam penugasan profesional audit sehingga independen seperti telah menjadi syarat mutlak yang harus dimiliki.

Teori atribusi mendukung pengaruh independensi terhadap kualitas hasil audit, bahwa perilaku auditor disebabkan oleh faktor internal dan faktor eksternal yang mempengaruhi kualitas hasil audit. Auditor yang memiliki sikap independen, maka hasil audit yang dihasilkan akan semakin berkualitas. Jika auditor kehilangan independensinya, maka laporan audit yang dihasilkan tidak sesuai kenyataan, sehingga tidak dapat digunakan sebagai dasar pengambilan keputusan.

Penelitian Alim et al. (2007) menunjukkan bahwa independensi berpengaruh signifikan terhadap kualitas audit. Berdasarkan penjelasan di atas, maka hipotesis yang diajukan adalah sebagai berikut ini.

H3: Independensi berpengaruh positif terhadap kualitas hasil pemeriksaan audit pemerintah

\section{Obyektifitas dan Kualitas Hasil Pemerik- saan}

Teori atribusi menjelaskan pengaruh obyektivitas terhadap kualitas hasil audit. Obyektivitas merupakan state of mind auditor, bahwa obyektifitas merupakan faktor internal yang mempengaruhi perilaku auditor. Seorang auditor yang mempertahankan obyektivitas, akan bertindak adil, tanpa adanya keberpihakan atau tekanan permintaan pihak tertentu atau kepentingan pribadinya, sehingga semakin tinggi tingkat obyektivitas auditor maka semakin baik kualitas audit yang dihasilkan.

Penelitian yang dilakukan oleh Sukriah et al. (2009) menemukan bahwa obyektifitas berpengaruh positif terhadap kualitas hasil Pemeriksaan. Semakin audi- 
tor mampu menjaga obyektifitas selama proses audit maka kualitas hasil audit akan semakin meningkat. Berdasarkan penjelasan di atas, maka hipotesis yang diajukan adalah sebagai berikut ini.

H4: Obyektifitas berpengaruh positif terhadap kualitas hasil pemeriksaan audit pemerintah

\section{Integritas dan Kualitas Hasil Pemeriksaan}

Teori atribusi menjelaskan pengaruh integritas terhadap kualitas hasil audit. Integritas merupakan faktor internal yang mempengaruhi auditor dalam melaksanakan tugas pemeriksaan. Auditor dituntut untuk memiliki kepribadian yang dilandasi oleh sikap jujur, berani, bijaksana, dan bertanggung jawab untuk membangun kepercayaan guna memberikan dasar bagi pengambilan keputusan yang handal (Pusdiklatwas BPKP 2008). Semakin tinggi integritas auditor dalam penugasan audit maka akan meningkatkan kualitas hasil audit.

Hasil penelitian dari Mabruri dan Winarna (2010) menemukan bahwa integritas berpengaruh signifikan terhadap kualitas hasil pemeriksaan, tetapi tidak sejalan dengan penelitian yang dilakukan Sukriah et al. (2009) yang menemukan bukti bahwa integritas auditor tidak berpengaruh signifikan terhdap kualitas hasil pemeriksaaan. Berdasarkan penjelasan diatas, maka hipotesis yang diajukan adalah sebagai berikut ini.

H5: Integritas auditor berpengaruh positif terhadap kualitas hasil pemeriksaan audit pemerintah

\section{Kompetensi dan Kualitas Hasil Pemerik- saan}

Kompetensi bagi auditor mempunyai dua dimensi yaitu; pengalaman dan pengetahuan. Auditor yang semakin berpengalaman dalam penugasan profesional audit akan dianggap mempunyai kompetensi yang tinggi. Selain itu auditor yang selalu meningkatkan pengetahuan tentang audit dan ilmu pendukungnya maka akan dianggap mempunyai kompetensi yang tinggi pula. Auditor harus memiliki pengetahuan untuk memahami entitas yang diaudit, kemudian auditor harus memiliki kemampuan untuk bekerja sama dalam tim serta kemampuan dalam menganalisis permasalahan.

Penelitian Alim et al. (2007) dan Efendy (2010), membuktikan bahwa kompetensi berpengaruh signifikan terhadap kualitas audit. Hal ini berarti bahwa kualitas audit dapat dicapai jika auditor memiliki kompetensi yang baik. Semakin auditor mempunyai kompetensi tinggi maka kualitas hasil audit akan semakin meningkat. Berdasarkan penjelasan diatas, maka hipotesis yang diajukan adalah:

H6: Kompetensi auditor berpengaruh positif terhadap kualitas hasil pemeriksaan audit pemerintah

\section{METODE PENELITIAN Populasi dan Sampel}

Populasi dalam penelitian ini adalah para auditor pemerintah yang merupakan PNS dan bekerja pada Kantor BPKP Perwakilan Provinsi DKI Jakarta tahun 2015. Sampel yang dipilih adalah auditor pemerintah yang telah mengikuti pendidikan dan pelatihan JFA (Jabatan Fungsional Auditor). Berdasarkan data pada bagian Biro Kepegawaian dan Organisasi tercatat jumlah auditor BPKP Perwakilan Provinsi DKI Jakarta sejumlah 105 orang. Penelitian ini menggunakan seluruh unsur populasi sebagai sumber data, maka penelitian ini bisa disebut dengan sensus. Sensus merupakan penelitian yang dianggap dapat mengungkapkan ciri-ciri populasi (parameter) secara akurat dan komprehensif, sebab dengan menggunakan seluruh unsur populasi sebagai sumber data, maka gambaran tentang populasi tersebut secara utuh dan menyeluruh dapat diperoleh.

\section{Jenis dan Sumber Data}

Jenis data dalam penelitian ini adalah data primer sedangkan sumber data dalam penelitian ini diperoleh dari jawaban kuesioner yang dibagikan kepada para auditor pemerintah sebagai PNS di BPKP Perwakilan DKI Jakarta. Kuesioner yang dikirimkan kepada responden merupakan kuesioner yang telah dikembangkan oleh Nataline (2007) dan Sukriah et al. (2009). 
Dalam penelitian ini pengukuran variabel menggunakan skala likert poin 5 dengan klasifikasi sebagai berikut; nilai 1 untuk jawaban Sangat Tidak Setuju (STS), 2 untuk jawaban Tidak Setuju (TS), 3 untuk jawaban Netral (N), 4 untuk jawaban Setuju (S), dan 5 untuk jawaban Sangat Setuju (SS).

\section{Metode Analisis Data}

Hipotesis dalam penelitian ini akan diuji dengan menggunakan analisis regresi berganda dan program SPSS for Windows Version 19.00. Persamaan regresinya adalah sebagai berikut :

$$
\begin{aligned}
\mathrm{Y}= & \beta 0+\beta 1 \mathrm{X} 1+\beta 2 \mathrm{X} 2+\beta 3 \mathrm{X} 3+\beta 4 \mathrm{X} 4+\beta 5 \mathrm{X} 5+ \\
& \beta 6 \mathrm{X} 6+\mathrm{e}
\end{aligned}
$$

\section{ANALISIS DAN PEMBAHASAN \\ Uji Validitas}

Berdasarkan data pengolahan data validitas, semua item pertanyaan valid dan dapat dimasukkan dalam pengolahan data selanjutnya.

Tabel 1.

\begin{tabular}{|c|c|c|c|c|c|}
\hline Variabel & $\begin{array}{c}\text { Item } \\
\text { per- } \\
\text { tanyaa } \\
\text { n }\end{array}$ & $\begin{array}{c}\text { Koefisien } \\
\text { Validitas }\end{array}$ & Variabel & $\begin{array}{c}\text { Item } \\
\text { per- } \\
\text { tanyaa } \\
\text { n }\end{array}$ & $\begin{array}{l}\text { Koefisien } \\
\text { Validitas }\end{array}$ \\
\hline \multirow{9}{*}{$\begin{array}{l}\text { Batas } \\
\text { Waktu } \\
\text { Audit } \\
\text { (X1) }\end{array}$} & X1_1 & 0,515 & \multirow{14}{*}{$\begin{array}{l}\text { Integritas } \\
\text { (X5) }\end{array}$} & X5_1 & 0,835 \\
\hline & $\mathrm{X} 1_{-} 2$ & 0,281 & & $\mathrm{X} 5 \_2$ & 0,807 \\
\hline & $\mathrm{X} 1_{-} 3$ & 0,334 & & $\mathrm{X} 5 \_3$ & 0,820 \\
\hline & $\mathrm{X} 1 \_4$ & 0,550 & & X5_4 & 0,753 \\
\hline & $\mathrm{X} 1 \_5$ & 0,644 & & X5_5 & 0,670 \\
\hline & X1_6 & 0,639 & & X5_6 & 0,788 \\
\hline & $\mathrm{X} 1_{-} 7$ & 0,579 & & X5_7 & 0,624 \\
\hline & $\mathrm{X} 1 \_8$ & 0,550 & & X5_8 & 0,671 \\
\hline & X1_9 & 0,549 & & X5_9 & 0,669 \\
\hline \multirow{8}{*}{$\begin{array}{l}\text { Pengala- } \\
\text { man (X2) }\end{array}$} & X2_1 & 0,781 & & X5_10 & 0,724 \\
\hline & X2_2 & 0,615 & & X5_11 & 0,828 \\
\hline & X2_3 & 0,760 & & X5_12 & 0,812 \\
\hline & X2_4 & 0,718 & & X5_13 & 0,819 \\
\hline & $\mathrm{X} 2 \_5$ & 0,685 & & X5_14 & 0,733 \\
\hline & X2_6 & 0,604 & \multirow{12}{*}{$\begin{array}{l}\text { Kompeten- } \\
\text { si (X6) }\end{array}$} & X6_1 & 0,577 \\
\hline & $\mathrm{X} 2 \_7$ & 0,489 & & X6_2 & 0,362 \\
\hline & X2_8 & 0,600 & & X6_3 & 0,755 \\
\hline \multirow{9}{*}{$\begin{array}{l}\text { Indepen- } \\
\text { densi (X3) }\end{array}$} & X3_1 & 0,598 & & X6_4 & 0,816 \\
\hline & X3_2 & 0,607 & & X6_5 & 0,773 \\
\hline & X3_3 & 0,558 & & X6_6 & 0,868 \\
\hline & X3_4 & 0,626 & & X6_7 & 0,815 \\
\hline & X3_5 & 0,422 & & X6_8 & 0,769 \\
\hline & X3_6 & 0,598 & & X6_9 & 0,798 \\
\hline & X3_7 & 0,612 & & X6_10 & 0,759 \\
\hline & X3_8 & 0,635 & & Y_1 & 0,824 \\
\hline & X3_9 & 0,666 & & Y_2 & 0,911 \\
\hline \multirow{8}{*}{$\begin{array}{l}\text { Obyektifi- } \\
\text { tas (X4) }\end{array}$} & X4_1 & 0,686 & \multirow{8}{*}{$\begin{array}{c}\text { Kualitas } \\
\text { Hasil Audit } \\
\text { Pemerintah } \\
\text { (Y) }\end{array}$} & Y_3 & 0,886 \\
\hline & $\mathrm{X} 4 \_2$ & 0,567 & & Y_4 & 0,732 \\
\hline & $\mathrm{X} 4 \_3$ & 0,849 & & Y_5 & 0,890 \\
\hline & X4_4 & 0,840 & & Y_6 & 0,874 \\
\hline & $\mathrm{X} 4 \_5$ & 0,815 & & Y_7 & 0,831 \\
\hline & X4_6 & 0,798 & & Y_8 & 0,829 \\
\hline & X4_7 & 0,769 & & Y_9 & 0,847 \\
\hline & X4_8 & 0,591 & & Y_10 & 0,805 \\
\hline
\end{tabular}

Uji Validitas

\section{Uji Reliabilitas}

Pengujian reliabilitas pernyataan dalam kuesioner menggunakan uji statistik cronbach's alpha. Kuesioner dapat dikatakan reliabel atau dapat diandalkan jika nilai cronbach's alpha $>$ 0,60 (Ghozali 2006). Hasil uji reliabilitas atas kuesioner menunjukkan bahwa kuesioner yang digunakan reliabel yaitu ditunjukkan dengan nilai cronbach's alpha seluruh variabel lebih besar dari 0,60.

Tabel 2.

Ringkasan Hasil Uji Reliabilitas

\begin{tabular}{clcl}
\hline NO & INDIKATOR & $\begin{array}{c}\text { Alpha } \\
\text { Cronbach }\end{array}$ & KETERANGAN \\
\hline 1 & $\begin{array}{l}\text { Batasan Waktu Audit } \\
(\mathrm{X} 1)\end{array}$ & 0,629 & Reliabel/Andal \\
2 & Pengalaman (X2) & 0,813 & Reliabel/Andal \\
3 & Independensi (X3) & 0,741 & Reliabel/Andal \\
4 & Obyektifitas (X4) & 0,882 & Reliabel/Andal \\
5 & Integritas (X5) & 0,939 & Reliabel/Andal \\
6 & Kompetensi (X6) & 0,893 & Reliabel/Andal \\
7 & Kualitas Hasil & 0,955 & Reliabel/Andal \\
& PemeriksaanAudit & & \\
& Pemerintahan (Y) & & \\
\hline
\end{tabular}

\section{Uji Asumsi Klasik}

Semua data dalam penelitian ini telah memenuhi uji asumsi klasik yang terdiri dari uji normalitas, uji multikolinieritas dan heteroskedastisitas.

\section{Uji F}

Hasil uji menunjukkan bahwa nilai probabilitas (Sig.) model regresi yang digunakan sebesar 0,000 lebih kecil dari tingkat signifikansi penelitian sebesar 0,1. Hal ini menunjukkan bahwa model regresi yang digunakan dalam penelitian layak (fit) untuk digunakan dalam pengujian hipotesis.

\section{Uji Hipotesis}

Alat statistik yang digunakan untuk menguji hipotesis adalah regresi linier berganda. Berdasarkan pengolahan data dapat diperoleh hasil regresi yang terlihat pada tabel sehingga diperoleh persamaan garis linier berganda sebagai berikut.

$\mathrm{Y}=2,840-0,130 \mathrm{X} 1+0,001 \mathrm{X} 2+0,168 \mathrm{X} 3+$ $0,108 \times 4+0,636 \times 5+0,136 \times 6$

Batasan Waktu Audit dan Kualitas Hasil Pemeriksaan Audit Pemerintah

Hasil pengujian regresi pada tabel 4 menunjukkan bahwa didapat nilai t hitung 
Tabel 3

Hasil Uji Signifikansi Simultan

\begin{tabular}{|c|c|c|c|c|c|c|}
\hline & Model & $\begin{array}{l}\text { Sum of } \\
\text { Squares }\end{array}$ & $\overline{D f}$ & Mean Square & $F$ & Sig. \\
\hline & $\begin{array}{l}\text { Regres- } \\
\text { sion }\end{array}$ & 1423,611 & 6 & 237,269 & 57,238 &, $000^{\mathrm{b}}$ \\
\hline 1 & Residual & 406,236 & 98 & 4,145 & & \\
\hline & Total & 1829,848 & 104 & & & \\
\hline & de & iable: $K$ & lita & asil Audit & & \\
\hline
\end{tabular}

batasan waktu audit terhadap kualitas hasil pemeriksaan audit pemerintahan sebesar 1,358 dengan tingkat signifikansi sebesar 0,178 . Dengan nilai signifikansi yang kurang dari 0,1 maka variabel batasan waktu audit tidak berpengaruh terhadap kualitas hasil pemeriksaan audit pemerintahan, sehingga $\mathrm{H} 1$ ditolak.

Dalam penugasan audit, auditor pemerintah biasanya sudah memiliki data awal tentang auditee karena klien dari auditor pemerintah adalah kementerian lembaga yang setiap tahunnya di audit, auditor tidak perlu lagi mempelajari karakteristik bisnis proses klien, karena auditor telah mempelajari perusahaan klien saat dia melakukan penugasan pertama kali sehingga pada saat melakukan audit di lapangan, auditor tinggal melakukan verifikasi data dan melakukan prosedur audit yang telah ditetapkan. Penetapan batasan waktu tidak realistis pada tugas audit, bila penetapan batasan waktu terlalu lama hal ini akan berdampak negatif pada biaya dan efektivitas pelaksanaan audit. Hasil ini tidak mendukung penelitian sebelumnya yang dilTabel 4

Hasil Uji Signifikansi-t

\begin{tabular}{|c|c|c|c|c|c|}
\hline \multirow[t]{2}{*}{ Variable } & \multicolumn{2}{|c|}{$\begin{array}{l}\text { standardized Coeffi- } \\
\text { cients }\end{array}$} & \multirow{2}{*}{$\begin{array}{c}\text { Standardized } \\
\text { Coefficients } \\
\text { Beta }\end{array}$} & \multirow[t]{2}{*}{ t } & \multirow[t]{2}{*}{ Sig. } \\
\hline & B & Std. Error & & & \\
\hline (Constant) & ,278 & 4,351 & & ,064 & ,949 \\
\hline Batas Waktu Audit &,- 130 & ,095 &,- 065 & $-1,358$ & , 178 \\
\hline Pengalaman & 001 & ,115 &, 000 & ,007 & ,995 \\
\hline Independensi & ,168 & ,090 & , 106 & 1,873 & ,064 \\
\hline Obyektifitas &,- 108 & ,124 &,- 073 &,- 868 & ,387 \\
\hline Integritas & ,636 & ,071 & ,816 & 8,893 & ,000 \\
\hline Kompetensi & 136 & ,078 &, 110 & 1,750 &, 083 \\
\hline
\end{tabular}

akukan Nataline (2007) yang menunjukkan bahwa para auditor merasa adanya kelonggaran dalam menjalankan tugasnya akan berdampak positif terhadap kualitas hasil auditnya, sebaliknya dengan waktu yang semakin sempit akan mengurangi kualitas auditnya.

\section{Pengalaman dan Kualitas Hasil Pemerik- saan Audit Pemerintah}

Hasil pengujian regresi pada tabel 4 menunjukkan bahwa didapat nilai t hitung pengalaman terhadap kualitas hasil pemeriksaan audit pemerintahan sebesar 0,007 dengan tingkat signifikansi sebesar 0,995. Dengan nilai signifikansi yang lebih dari 0,1 maka variabel pengalaman tidak berpengaruh terhadap kualitas hasil pemeriksaan audit pemerintahan. Hal ini menunjukkan semakin berpengalamannya auditor pemerintah dalam melakukan audit tidak mempengaruhi kualitas hasil pemeriksaan yang dihasilkan. Dengan demikian dapat disimpulkan bahwa $\mathrm{H} 2$ ditolak. Artinya variabel pengalaman tidak berpengaruh terhadap kualitas hasil pemeriksaan audit.

Dalam penugasan profesionalnya, auditor pemerintah dituntut mampu menjaga kualitas hasil pemeriksaan dengan baik. Tuntutan ini membuat mereka harus mengikuti prosedur audit secara profesional sehingga mereka yang baru bekerja sebagai auditor pemerintah maupun yang sudah berpengalaman wajib menjaga kualitas hasil pemeriksaan audit pemerintahan.

Hasil ini mendukung penelitian Singgih dan Bawono (2010) serta Badjuri (2012). Tetapi penelitian ini tidak sejalan dengan Suraida (2005) dan Sukriah et al. (2009) yang menyatakan bahwa pengalaman berpengaruh terhadap kualitas hasil audit.

\section{Independensi dan Kualitas Hasil Pemerik- saan Audit Pemerintah}

Hasil pengujian regresi pada tabel 4 menunjukkan bahwa didapat nilai t hitung independensi terhadap kualitas hasil pemeriksaan audit pemerintahan sebesar 1,873 dengan tingkat signifikansi sebesar 0,064. Dengan nilai signifikansi yang kurang dari 0,1 maka variabel independensi 
berpengaruh positif terhadap kualitas hasil pemeriksaan audit pemerintahan, sehingga H3 diterima.

Independensi merupakan standar auditing bagi seorang auditor sehingga mutlak baginya pada saat melakukan penugasan profesionalnya. Faktor independensi memang melekat pada diri auditor ketika auditor tidak mampu menjaga independensinya maka dia sudah melakukan pelanggaran etika. Bagi auditor pemerintah, independensi sangat ditekankan pada saat penugasan audit karena mereka pada dasarnya melakukan audit terhadap lembaga pemerintah dan auditee-nya adalah sesama PNS. Pelanggaran etika independensi bagi auditor pemerintah dapat berdampak pada sanksi pidana dan pemecatan sebagai APIP. Jadi, semakin independen seorang auditor maka semakin baik juga kualitas hasil pemeriksaannya.

Hasil Pengujian ini mendukung hasil penelitian yang dilakukan oleh Christiawan (2002), Trisnaningsih (2007) dan Alim et al (2007) yang menyatakan independensi berpengaruh terhadap kualitas audit.

\section{Obyektifitas dan Kualitas Hasil Pemerik- saan Audit Pemerintah}

Hasil pengujian regresi pada tabel 4 menunjukkan bahwa didapat nilai t hitung obyektifitas terhadap kualitas hasil pemeriksaan audit pemerintahan sebesar 0,868 dengan tingkat signifikansi sebesar 0,387 . Dengan nilai signifikansi yang lebih dari 0,1 maka variable obyektifitas tidak berpengaruh terhadap kualitas hasil pemeriksaan audit pemerintahan, sehingga H4 ditolak.

Pada dasarnya auditor pemerintah wajib melakukan audit berdasarkan obyektifitas tetapi dimungkinkan dalam kenyataannya unsur subjektifitas mungkin muncul. Obyektifitas merupakan aturan etika bagi auditor sehingga mutlak baginya pada saat melakukan penugasan profesionalnya sehingga unsur ini memang harus melekat pada dirinya. Ketika auditor tidak mampu menjaga obyektifitasnya maka dia sudah melakukan pelanggaran etika. Bagi auditor pemerintah, obyektifitas sangat ditekankan pada saat penugasan audit karena mereka pada dasarnya melakukan au- dit terhadap lembaga pemerintah dan auditeenya adalah sesama PNS. Pelanggaran etika obyektifitas bagi auditor pemerintah dapat berdampak pada sanksi pidana dan pemecatan sebagai APIP.

Hasil penelitian ini sejalan dengan hasil penelitian Badjuri (2012), tetapi tidak sejalan dengan hasil penelitian Sukriah et al. (2009).

\section{Integritas dan Kualitas Hasil Pemeriksaan Audit Pemerintah}

Hasil pengujian regresi pada tabel 4 menunjukkan bahwa didapat nilai t hitung integritas terhadap kualitas hasil pemeriksaan audit pemerintahan sebesar 8,893 dengan tingkat signifikansi sebesar 0,000. Dengan nilai signifikansi yang kurang dari 0,1 maka variabel integritas berpengaruh positif terhadap kualitas hasil pemeriksaan audit pemerintahan, sehingga H5 diterima. Hal ini menunjukkan bahwa semakin tinggi integritas auditor pemerintah, semakin baik pula kualitas hasil pemeriksaan yang dihasilkan.

Integritas merupakan perwujudan dari kejujuran auditor dalam melakukan penugasan profesionalnya. Dengan kejujuran dalam mengungkapkan temuan audit maka kualitas hasil pemeriksaan akan terjaga. Bagi auditor pemerintah, penugasannya akan membawa konsekuensi hukum karena obyek auditnya adalah penggunaan keuangan negara yang rentan terhadap korupsi Dalam pengungkapan temuan kasus-kasus korupsi diperlukan adanya kejujuran (integritas) para auditornya sehingga pengungkapan kasusnya akan menjadi transparan dan menjaga rasa keadilan pada masyarakat.

Penelitian ini juga mengindikasikan bahwa auditor pemerintah harus selalu memegang teguh prinsip integritas yang mengharuskannya untuk memiliki kepribadian yang dilandasi oleh unsur kejujuran, keberanian, bijaksana, dan bertanggung jawab untuk membangun kepercayaan publik dan dasar pengambilan keputusan yang andal. Hasil penelitian ini mendukung penelitian Mabruri dan Winarna (2010) tetapi tidak sejalan dengan penelitian yang dilakukan Sukriah et al. (2009) yang menemukan bukti bahwa integ- 
ritas auditor tidak berpengaruh terhadap kualitas hasil pemeriksaan.

\section{Kompetensi dan Kualitas Hasil Pemerik- saan Audit Pemerintah}

Hasil pengujian regresi pada tabel 4 menunjukkan bahwa didapat nilai t hitung integritas terhadap kualitas hasil pemeriksaan audit pemerintahan sebesar 1,750 dengan tingkat signifikansi sebesar 0,083. Dengan nilai signifikansi yang kurang dari 0,1 maka variabel integritas berpengaruh positif terhadap kualitas hasil pemeriksaan audit pemerintahan, sehingga H6 diterima. Hal ini menunjukkan bahwa semakin tinggi kompetensi auditor pemerintah, semakin baik pula kualitas hasil pemeriksaan yang dihasilkan.

Kompetensi merupakan salah satu faktor keberhasilan dalam penugasan audit. Kompetensi audit diperlukan bagi audit pada lembaga pemerintah karena banyak prosedur audit dan standar yang harus dipahami oleh auditor. Kompetensi auditor pemerintah bisa dibangun melalui pelatihan-pelatihan rutin yang sering dilakukan oleh BPKP dalam rangka membangun kompetensi auditor.

Jika auditor pemerintah memiliki kompetensi yang baik maka ia akan mudah dalam melaksanakan tugas profesional auditnya. Sebaliknya, jika kompetensi auditor pemerintah tersebut rendah, maka dalam melaksanakan tugasnya ia akan mengalami kesulitan dalam penugasan profesional auditnya, sehingga dimungkinkan kualitas hasil pemeriksaan yang dihasilkan akan rendah pula. Hasil penelitian ini mendukung penelitian yang telah dilakukan Badjuri (2012), Suraida (2005), Alim et al. (2007) dan Sukriah et al. (2009).

\section{SIMPULAN}

Penelitian ini membuktikan bahwa independensi, integritas dan kompetensi auditor pemerintah berpengaruh positif dan signifikan terhadap kualitas hasil pemeriksaan yang dihasilkan. Hal ini menunjukkan bahwa semakin tinggi independensi, integritas dan kompetensi yang dimiliki oleh auditor pemerintah pada saat melaksanakan penugasan profesional auditnya akan mendorong meningkatnya kualitas hasil pemeriksaan yang dihasilkan. Auditor pemerintah diharapkan selalu menjaga independensi, integritas, dan meningkatkan kompetensinya dalam bertugas sebagai wujud pertanggungjawaban kepada masyarakat yang menjadi salah satu pihak pengguna hasil audit pemerintah.

Penelitian ini juga membuktikan bahwa batasan waktu audit, pengalaman kerja audit, dan obyektifitas auditor pemerintah tidak berpengaruh terhadap kualitas hasil pemeriksaan. Hal ini menunjukkan bahwa batasan waktu yang ditentukan tidak membuat kualitas hasil pemeriksaan menjadi lebih baik, semakin auditor sektor publik yang berpengalaman dalam melakukan audit ternyata belum tentu dapat meningkatkan kualitas hasil pemeriksaan. Begitu juga dengan obyektifitas auditor pemerintah pada saat melakukan penugasan profesional audit ternyata belum tentu dapat meningkatkan kualitas hasil pemeriksaan.

\section{KETERBATASAN DAN SARAN}

Penelitian ini memiliki beberapa keterbatasan yang memerlukan perbaikan dan pengembangan dalam penelitian selanjutnya. Keterbatasan dalam penelitian ini adalah menggunakan metode survei melalui kuesioner, peneliti tidak melakukan wawancara atau terlibat langsung dalam aktivitas di BPKP Perwakilan Provinsi DKI, sehingga data yang diperoleh hanya berdasarkan pada data yang dikumpulkan melalui instrument secara tertulis. Kelemahan pendekatan survei melalui kuesioner ini umumnya terletak pada internal validity. Selain dari sisi metode penelitian yang digunakan, keterbatasan lainnya yaitu dalam penelitian ini pengukuran kualitas hasil pemeriksaan hanya ditinjau dari aspek pelaksanaan audit, sehingga untuk penelitian selanjutnya dapat meninjau dari aspek yang lain.

Saran yang dapat diberikan oleh peneliti adalah peneliti yang akan datang disarankan untuk melakukan pengujian dengan memperluas lingkup responden pada instansi auditor pemerintah yang lain, misalnya; BPK, Bapeda Provinsi/ Kabupaten/Kota, Inspektorat Jenderal kementerian, Inspektorat Utama/Inspektorat LPND dan unit kerja bidang pengawasan 
pada instansi pemerintah lainnya. Berdasarkan nilai adjusted $R$ Square sebesar 0,778 maka masih terdapat variable independen lain yang dapat diduga berpengaruh terhadap kualitas hasil pemeriksaan sehingga dapat mendorong peneliti selanjutnya untuk mencari variable lain yang diduga dapat mempengaruhi kualitas hasil pemeriksaan. Dalam penelitian selanjutnya diharapkan peneliti melakukan wawancara atau terlibat langsung dalam aktivitas obyek penelitian, sehingga dapat diperoleh hasil penelitian yang valid.

\section{DAFTAR PUSTAKA}

Alim, M.N., T. Hapsari dan L. Purwanti. 2007. Pengaruh Kompetensi dan Independensi terhadap Kualitas Audit dengan Etika Auditor sebagai Variabel Moderasi. Simposium Nasional Akuntansi X, Makassar, Indonesia.

Badjuri, A. 2012. Analysis Faktor-Faktor Yang Mempengaruhi Kualitas Hasil Pemeriksaan Audit Sektor Publik. Dinamika Akuntansi, Keuangan dan Perbankan, 1 (2): 120-135.

BPK (Badan Pemeriksa Keuangan). 2007. Peraturan Badan Pemeriksa Keuangan Republik Indonesia Nomor 01 tahun 2007 tentang Standar Pemeriksaan Keuangan Negara.

Christiawan, Y.J. 2002. Kompetensi dan Independensi Akuntan Publik: Refleksi Hasil Penelitian Empiris. Journal Directory: Kumpulan Jurnal Akuntansi dan Keuangan Unika Petra, 4 (2): 79-92.

De Angelo, L.E. 1981. Auditor Independence, "Low Balling", And Disclosure Regulation. Journal of Accounting And Economics, 3 (2): 113-127.

Efendy, M.T. 2010. Pengaruh Kompetensi, Independensi Dan Motivasi Terhadap Kualitas Audit Aparat Inspektorat Dalam Pengawasan Keuangan Daerah. Tesis, Universitas Diponegoro, Semarang.

Ghozali, I. 2006. Aplikasi Analisis Multivariate Dengan Program SPSS. Semarang: Badan Penerbit Universitas Diponegoro.

Gujarati, D. 2003. Ekonometri Dasar (Terjemahan). Jakarta: Erlangga.
IAI (Ikatan Akuntan Indonesia). 2001. Pernyataan Standar Auditing (PSA) No. 70: Perimbangan atas Kecurangan dalam Audit Laporan Keuangan. Jakarta: IAI.

Luthans, F. 2005. Perilaku Organisasi (Terjemahan). Edisi Kesepuluh. Yogyakarta: Andi.

Mabruri dan Winarna. 2010. Analisis Faktor -Faktor yang Mempengaruhi Kualitas Hasil Audit di Lingkungan Pemerintah Daerah. Simposium Nasional Akuntansi XIII, Purwokerto, Indonesia.

Manulang. 1984. Manajemen Personalia. Jakarta: Ghalia Indonesia.

Mardiasmo. 2006. Pewujudan Transparansi dan Akuntabilitas Publik Melalui Akuntansi Sektor Publik: Suatu Sarana Good Governance. Jurnal Akuntansi Pemerintah, 2 (1): 1-17. .. 2002. Akuntansi Sektor Publik. Yogyakarta: ANDI.

Menpan (Kementrian Pendayagunaan Aparatur Negara dan Reformasi Birokrasi). 2008. Permenpan Nomor PER/04/M.PAN/03/2008 tentang Kode Etik Aparat Pengawasan Intern Pemerintah.

2008. Permenpan Nomor PER/05/M.PAN/03/2008 tentang Standar Audit Aparat Pengawasan Intern Pemerintah.

Mulyadi. 2002. Auditing (Buku Dua). Edisi Keenam. Jakarta: Salemba Empat.

Nataline. 2007. Pengaruh Batasan Waktu Audit, Pengetahuan Akuntansi dan Auditing, Bonus serta Pengalaman terhadap Kualitas Audit pada Kantor Akuntan Publik di Semarang. Tesis, Fakultas Ekonomi Universitas Negeri Semarang, Semarang.

Parasayu, A. dan A. Rohman. 2014. Analisis Faktor-faktor yang Mempengaruhi Kualitas Hasil Audit Internal (Study Persepsi Aparat Intern Pemerintah Kota Surakarta dan Kabupaten Boyolali. Diponegoro Journal of Accounting, 3 (2): 1-10.

Pusdiklatwas BPKP. 2008. Modul Diklat Pembentukan Auditor Ahli: Kode Etik Dan Standar Audit. Bogor.

Republik Indonesia. 2008. Peraturan 
Pemerintah Nomor 60 tahun 2008 tentang Sistem Pengendalian Intern Pemerintah.

Sekaran, U. 2013. Research Methods for Business. Sixth Edition. UK: Wiley.

Singgih dan I.R. Bawono. 2010. Pengaruh Independensi, Pengalaman, Due Professional Care dan Akuntabilitas terhadap Kualitas Audit. Simposium Nasional Akuntansi XIII, Purwokerto, Indonesia.

Sukriah, I. Akram dan B.A. Inapty. 2009. Pengaruh Pengalaman Kerja, Independensi, Obyektifitas, Integritas dan Kompetensi terhadap Kualitas Hasil Pemeriksaan. Simposium Nasional Akuntansi XII. Palembang, Indonesia. Sunarsip. 2001. Kepemimpinan Transfor- masional dalam Era Perubahan Organisasi. Jurnal Managemen dan Bisnis, 5 (2): 106-116.

Suraida, I. 2005. Pengaruh Etika, Kompetensi, Pengalaman Audit dan Risiko Audit terhadap Skeptisme Profesional Auditor dan Ketepatan Pemberian Opini Akuntan Publik. Sosiohumaniora, 7 (3): 186-202.

Trisnaningsih, S. 2007. Independensi Auditor dan Komitmen Organisasi sebagai Mediasi Pengaruh Pemahaman Good Corporate Governance, Gaya Kepemimpinan dan Budaya Organisasi terhadap Kinerja Auditor. Simposium Nasional Akuntansi X, Makassar, Indonesia. 
